\title{
Efficient synthesis of plant-mediated silver nanoparticles and their screening for antimicrobial activity
}

\author{
Rashmi Dwivedi, ${ }^{1}$ Bhoopander Giri, ${ }^{2}$ and Kamlesh Shukla ${ }^{3^{*}}$ \\ ${ }^{1}$ Department of Biotechnology, Guru Ghasidas Central University, Bilaspur, India \\ ${ }^{2}$ Department of Botany, Swami Shraddhanand College, University of Delhi, Delhi, India \\ ${ }^{3}$ Department of Biotechnology, Pt. Ravishankar Shukla University, Raipur, India
}

\section{Article history}

Received: 08 August 2017

Accepted: 01 September 2017

Published: 11 September 2017

(c) Dwivedi et al. (2017)

Editor

K K Sabu

Publisher

Horizon e-Publishing Group

Correspondence

Kamlesh Shukla

$\bowtie$ kshukla26@yahoo.co.in

\begin{abstract}
Now days, the development of safe, cost effective, reliable and eco-friendly processes for the synthesis of nanoparticles is an important aspect of nanotechnology. Among the various agents, plants show immense potential for the synthesis of nanoparticles. The bio-molecules found in plants induce reduction of $\mathrm{Ag}^{+}$ions from silver nitrate to silver nanoparticles (AgNPs); therefore, in the present work, the aqueous leaves extract of the plant was used as reducing agent for the synthesis of silver nanoparticles. We synthesized extracellular silver nanoparticles using extract of the leaves of four different medicinal plants which act as a reducing agent at room temperature. The characteristic color change was observed on addition of plant extract to the silver nitrate solution due to their specific properties (Surface Plasmon Resonance). UV-Vis spectroscopy was used for the characterization of the silver nanoparticles. Green synthesized nanoparticles are evaluated for their antimicrobial activity against the Gram-positive and Gram-negative bacteria as well as two pathogenic fungi Aspergillus fumigatus and Curvularia lunata. The silver nanoparticles (SNPs) of selected plant parts have shown more toxicity towards bacterial species than that of the fungal species. Comparing with simple plant extracts, the SNPs exhibited greater antimicrobial efficacy and advantage over conventional antibiotics to which these microorganisms usually impart resistance.
\end{abstract}

\section{Keywords}

SNPs; Plant extract; Antimicrobial activity; Nanobiotechnology

\section{Citation}

Dwivedi R, Giri B, Shukla K. Efficient synthesis of plant-mediated silver nanoparticles and their screening for antimicrobial activity. Plant Science Today 2017;4(3):143-150. doi: 10.14719/pst.2017.4.3.328

\section{Introduction}

Nanotechnology refers to an extensive area of research with a unifying theme of controlling matter size from micrometer to nanometer which is known as nanoparticles, which constitute the fundamental building blocks of nanotechnology. Owing to their extensive applications, several artificial methods have been developed 
for the synthesis of nanoparticles (1). Since metal nanoparticles show potent industrial applications, there is a growing interest in the biological and environmentally safe production of such particles. The artificial methods of nanoparticle synthesis include chemical and physical approaches, which are often expensive and potentially harmful to the environment. Recently, various biological methods such as use of microorganism $(2,3)$, enzyme (4) and plant extract (5-7) have been increasingly considered as an alternative approach for the production of nanoparticles with specified properties.

Amongst these, plant extract offers several advantages over others as it is efficient, inexpensive, non-toxic and eco-friendly method of nanoparticles production (8). Previous studies revealed that the size, morphology, stability, and physicochemical properties of metal nanoparticles are strongly influenced by the experimental conditions (9-11). This property is predominantly significant for noble metals such as silver and gold, which have strong surface plasmon resonance oscillations (12). The antibacterial and antifungal properties of copper, silver, titanium and zinc efficiently control the growth of various microorganisms $(13,14)$. A number of studies have shown that AgNPs prepared using plant extract exhibit higher antibacterial activity and strong toxicity against a wide range of microorganisms. Therefore, silver-based compounds have been used widely in many bactericidal applications. Excessive dosage and intensive use of antibiotics have brought the bacteria on the brink of increasing resistance against antibiotics, which necessitate an urgent need to develop efficient and cost-effective approaches for antibiotics development.

SNPs have been found to be a good substitute as these confers an inhibitory effect against many pathogens, particularly bacteria and fungi $(15,16)$. The SNPs are increasingly being used in medicine to reduce infections in burn treatment and arthroplasty to prevent bacterial colonization on prostheses (17), catheters (18), vascular grafts, dental materials $(19,20)$, stainless steel materials (21) and human skin (22). SNPs also exhibit a potent cytoprotective activity towards HIVinfected cells (23). In view of the importance of plant-mediated SNPs in medicine, the aqueous leaf extracts of three different medicinal plants i.e. Punica granatum, Aegle marmelos and Datura innoxia have been used as a reducing and stabilizing agent to synthesize silver nanoparticles. The silver nitrate was reduced to metallic silver on reaction with leaf extract of above mentioned medicinal plants, resulting in the synthesis of silver nanoparticles. The silver nanoparticles formed were characterized using ultravioletvisible spectroscopy. Antimicrobial assays using silver nanoparticles demonstrated activity against both the bacteria and fungi tested.

\section{Materials and methods}

\subsection{Collection of plant materials and extract}

The leaves of selected medicinal plants were collected from the experimental field of Guru Ghasidass University Bilaspur, Chattisgarh, India (Table 1). The leaves were thoroughly washed with distilled water to remove any traces of debris adhere to it and chopped into small pieces. The $5 \mathrm{gm}$ of washed and chopped leaves are taken in a $250 \mathrm{ml}$ Erlenmeyer flask with $100 \mathrm{ml}$ of milli-Q water and this mixture was boiled for 15-20 min $(24,25)$. The herbal aqueous extract was filtered in the separate conical flasks by standard filtration method using Whatman no. 1 filter paper and stored at $4^{\circ} \mathrm{C}$. The leaf extract acts as a reducing agent for the synthesis of nanoparticles.

\subsection{Synthesis and characterization of silver nanoparticles}

Three different plant extracts of medicinal importance was used for the synthesis of silver nanoparticles. Silver nitrate $\left(\mathrm{AgNO}_{3}\right)$ solution was used as a source of metal for nanoparticle synthesis according to the process as given by Zargar et al (23). The $10 \mathrm{ml}$ of filtered plant extract was added to $90 \mathrm{ml}$ of aqueous solution of $1 \mathrm{mM}$ silver nitrate $\left(\mathrm{AgNO}_{3}\right)$ for the reduction of silver nitrate into $\mathrm{Ag}^{+}$ions and kept for the incubation at room temperature. After 10-15 $\mathrm{min}$, the color of the solution changed into yellowish orange and blackish, this indicates the formation of silver nanoparticles. The reduced silver nanoparticles solution was filtered through Whatman no.1 filter paper and the filtrate was qualitatively characterized and measured by UV-Visible absorbance (Spectrophotometer UV-vis 1800, Shimadzu, Kyoto, Japan).

\subsection{UV-Visible spectra analysis}

There are various techniques used for characterizing nanoparticles. However, nanoparticles characterization generally subject to their size, shape, surface area and dispersity. The preliminary and convenient way for nanoparticles characterization is the observation of color change with the addition of $\mathrm{AgNO}_{3}$ solution. UV-vis spectral analysis was done by using UV-vis spectrophotometer at a resolution of $1 \mathrm{~nm}$ in the range $900-1100 \mathrm{~nm}$. The reduction of pure $\mathrm{Ag}^{+}$ions to $\mathrm{Ag}^{0}$ was monitored by measuring the UVvis spectrum with the sampling of aliquots $(0.1 \mathrm{ml})$ of AgNPs solution and diluting the sample in $3 \mathrm{ml}$ distilled water. The de-ionized water was used for all UV-vis spectrum background correction. Spectra were obtained by loading the prepared SNP sample into a $1 \mathrm{~cm}$ path length cuvette.

\subsection{Antimicrobial activity}

The antimicrobial activity of phytosynthesized AgNPs was assayed against both specific bacterial and fungal pathogens using agar well-diffusion method as given by Perez et al. (26). 
Table 1: Scientific and common names of medicinal plants used for the synthesis of AgNP

\begin{tabular}{|c|c|c|c|c|}
\hline S.No. & Scientific Name & Family & Common Name & Medicinal Name \\
\hline 1. & Punica granatum & Lythraceae & Anar & $\begin{array}{l}\text { For treatment of osteoarthritis, sore throats, } \\
\text { coughs, urinary infections, digestive disorders, } \\
\text { skin disorders, arthritis, and to expel tapeworms }\end{array}$ \\
\hline 2. & Datura innoxia & Solanaceae & Datura, Thorn Apple & Antiasthmatic, febrifuge, antipertussive \\
\hline 3. & Aegle marmelos & Rutaceae & Bael & $\begin{array}{l}\text { for the treatment of various disorders in human } \\
\text { being such as, diabetes, liver toxicity, fungal } \\
\text { infection, microbial infection, inflammation, } \\
\text { pyrexia and to relieve pain }\end{array}$ \\
\hline
\end{tabular}

Table 2: Antibacterial activity of silver nanoparticles and Plant extracts. Values (mean \pm SD) are average of test samples of $\mathrm{AgNO}_{3}$, AgNPs and plant extracts analyzed individually in triplicate (n = 1X 3)

\begin{tabular}{|c|c|c|c|}
\hline \multirow[t]{2}{*}{ Name of the test microorganisms } & \multicolumn{3}{|c|}{ Zone of inhibition $(\mathrm{mm})$ average \pm standard deviation (SD) } \\
\hline & $\mathrm{AgNO}_{3}$ & AgNPs & Punica granatum \\
\hline $\begin{array}{l}\text { Gram positive } \\
\text { (Staphylococcus aureus) }\end{array}$ & $5.00 \pm 1.00$ & $10.33 \pm 1.52$ & $4.65 \pm 1.15$ \\
\hline $\begin{array}{l}\text { Gram negative } \\
\text { (Enterobactor aerogens) }\end{array}$ & $9.33 \pm 0.57$ & $16.33 \pm 1.52$ & $5.67 \pm 1.52$ \\
\hline \multirow[t]{2}{*}{ Name of the test microorganisms } & \multicolumn{3}{|c|}{ Zone of inhibition $(\mathrm{mm})$ average \pm standard deviation (SD) } \\
\hline & $\mathrm{AgNO}_{3}$ & AgNPs & Aegle marmelos \\
\hline $\begin{array}{l}\text { Gram positive } \\
\text { (Staphylococcus aureus) }\end{array}$ & $7.33 \pm 1.52$ & $10.67 \pm 1.15$ & $4.33 \pm 0.57$ \\
\hline $\begin{array}{l}\text { Gram negative } \\
\text { (Enterobactor aerogens) }\end{array}$ & $7.67 \pm 1.15$ & $19.00 \pm 1.00$ & $4.67 \pm 0.57$ \\
\hline \multirow[t]{2}{*}{ Name of the test microorganisms } & \multicolumn{3}{|c|}{ Zone of inhibition (mm) average \pm standard deviation (SD) } \\
\hline & $\mathrm{AgNO}_{3}$ & AgNPs & Datura innoxia \\
\hline $\begin{array}{l}\text { Gram positive } \\
\text { (Staphylococcus aureus) }\end{array}$ & $9.33 \pm 0.57$ & $12.67 \pm 1.15$ & $6.33 \pm 0.57$ \\
\hline $\begin{array}{l}\text { Gram negative } \\
\text { (Enterobactor aerogens) }\end{array}$ & $10.33 \pm 1.52$ & $15.33 \pm 0.57$ & $7.00 \pm 1.73$ \\
\hline
\end{tabular}

Table 3: Antifungal activity of silver nanoparticles and Plant extracts. Values (mean \pm SD) are average of test samples of $\mathrm{AgNO}_{3}, \mathrm{AgNPs}$ and plant extract analyzed individually in triplicate ( $\left.\mathrm{n}=1 \mathrm{X} 3\right)$

\begin{tabular}{|c|c|c|c|}
\hline \multirow{2}{*}{$\begin{array}{l}\text { Name of the test } \\
\text { microorganisms }\end{array}$} & \multicolumn{3}{|c|}{ Zone of inhibition $(\mathrm{mm})$ average \pm standard deviation (SD) } \\
\hline & $\mathrm{AgNO}_{3}$ & AgNPs & Punica granatum \\
\hline Curvularia lunata & $9.33 \pm 0.57$ & $10.67 \pm 1.00$ & $6.67 \pm 0.57$ \\
\hline Aspergillus fumigatus & $7.67 \pm 1.15$ & $15.33 \pm 0.57$ & $5.00 \pm 1.00$ \\
\hline \multirow[t]{2}{*}{ Name of the test micro } & \multicolumn{3}{|c|}{ Zone of inhibition (mm) average \pm standard deviation (SD) } \\
\hline & $\mathrm{AgNO}_{3}$ & AgNPs & Aegle marmelos \\
\hline Curvularia lunata & $6.33 \pm 0.57$ & $15.67 \pm 0.57$ & $4.33 \pm 0.57$ \\
\hline Aspergillus fumigatus & $9.33 \pm 0.57$ & $19.00 \pm 1.00$ & $6.00 \pm 1.00$ \\
\hline \multirow[t]{2}{*}{ Name of the test micro } & \multicolumn{3}{|c|}{ Zone of inhibition (mm) average \pm standard deviation (SD) } \\
\hline & $\mathrm{AgNO}_{3}$ & AgNPs & Datura innoxia \\
\hline Curvularia lunata & $8.67 \pm 1.52$ & $16.67 \pm 1.15$ & $4.67 \pm 1.15$ \\
\hline Aspergillus fumigatus & $7.33 \pm 1.52$ & $19.67 \pm 0.57$ & $5.67 \pm 1.52$ \\
\hline
\end{tabular}




\subsubsection{Antibacterial}

Gram positive (Staphylococcus aureus) and Gram negative (Enterobactor aerogens) bacteria were used in the antimicrobial assay. The fresh inoculums of Gram positive and Gram negative bacteria was prepared by growing a single colony overnight in nutrient broth at $35^{\circ} \mathrm{C}$. The optical densities (OD) of incubated bacteria in nutrient broth were recorded in UV spectrophotometer (Shimadzu, Japan) at wavelength $600 \mathrm{~nm}$. The optimal desired standard optical density (OD) was obtained as $0.45-0.55$, attaining the turbidity to 0.5 McFarland standards (108 CFU/mL). The turbidity was set to the desired range by dilution or otherwise again incubation done if OD were less than the standards values.

The sterilized solid Nutrient agar medium (NAM) plates were swabbed uniformly with bacterial pathogens. In the experiment, all chemicals used were of commercial grade and purchased from Merck, Germany). Circular well of $6 \mathrm{~mm}$ diameter were punched in NAM agar plates using a sterile cork-borer. The wells were filled with 10-50 $\mathrm{\mu l}$ of $\mathrm{AgNO}_{3}, \mathrm{AgNPs}$ and Plant extracts. The plates were incubated at $37^{\circ} \mathrm{C}$ for $24 \mathrm{~h}$. After incubation period, the diameters of zone of inhibition produced with different organisms were measured in $(\mathrm{mm})$ and recorded by using Zonal scale.

\subsubsection{Antifungal}

The antifungal activity of AgNPs was assayed against Curvularia lunata and Aspergillus fumigatus by using agar well-diffusion technique on potato dextrose agar (PDA) as given by Talibi et al (27). The $100 \mu$ l of fungal species suspension was inoculated onto the solid of $\mathrm{AgNO}_{3}, 10-50 \mu \mathrm{l}$ of AgNPs and plant extracts. The plates were incubated at $(28 \pm 2){ }^{\circ} \mathrm{C}$ for $72 \mathrm{~h}$. Evaluation for each test extract form was done in 3 replicates. After incubation for required period, the zone of inhibition produced were recorded. A clear zone of inhibition observed around the well gives indications of antifungal activity for respective used extract and were measured in ( $\mathrm{mm}$ ) by using Zonal scale.

\subsection{Statistical analysis}

Statistical analysis was carried out using SPSS Version 16 for the assessment of mean comparisons. The results expressed in terms of mean \pm standard deviation. All data presented are obtained from mean values of triplicate measurements ( $\mathrm{n}=3)$, obtained from three individual runs.

\section{Results and Discussion}

SNPs with their unique properties are proving to be an excellent method for the generation of new effective antibacterial agents. The synthesis of nanoparticles using plants material is an alternative way in which the important secreted biomolecules serves both as reducing and capping agent during the reaction. It is considered as green chemical process as it minimizes the use of toxic chemical agents (28.29). The plant-mediated synthesis of metal nanoparticles has shown to produce nanoparticle of shape and size, which is comparable with those which are produced through physical and chemical techniques (30). In order to achieve this target, researchers have paid their interest towards green synthesis of nanoparticles because of its eco-friendly route (31).

A study on the green synthesis of AgNPs by using Punica granatum, Aegle marmelos and Datura innoxia were carried. As the leaf extracts were mixed with the aqueous solution of silver nitrate, color changes from yellowish orange to brown or blackish, nanoparticles (32), which indicated the synthesis of silver nanoparticles. This color change was due to the reduction of $\mathrm{Ag}^{+}$ into $\mathrm{Ag}$, which indicates the formation of silver nanoparticles. The reduction rate and formation of nanoparticles can be amplified further by increase in temperature (33). Similar observations of the colour change in the colloidal solution were reported, indicating the formation of AgNPs, due to the result of excitation of surface plasmon phenomena in SNPs (34).

\subsection{UV-Vis Spectra Analysis}

UV-Vis spectroscopy is the preliminary technique for the characterization of the silver nanoparticles. It is an indirect method generally used to examine the bio-reduction of SNPs from aqueous $\mathrm{AgNO}_{3}$ solution. The UV-vis spectroscopy is generally a technique usually employed for characterizing the synthesized SNPs owing to the surface Plasmon phenomenon (SPR). Morphology of the nanoparticles is very much influenced by the SPR, as it is the basis for measuring adsorption of material onto the surface of metal nanoparticles (35). The reduction of $\mathrm{AgNO}_{3}$ to SNPs on addition of different plant extracts was confirmed by observing colour change and UV-vis spectrum. The $\mathrm{AgNO}_{3}$ solution was prepared, added to the plant extract samples and allowed for heating at $90^{\circ} \mathrm{C}$ for $10 \mathrm{~min}$. The color change was observed due to the reduction of $\mathrm{Ag}^{+}$to $\mathrm{Ag}^{0}$ due to the presence of various types of biomolecules in the plant extract (36). The absorption spectra of AgNPs of three various plant extracts were recorded using UV-Vis spectroscopy. The UV-Vis absorption spectra displayed the characteristic absorption peak at a wavelength of $203 \mathrm{~nm}, 204.5 \mathrm{~nm}$ and $197.5 \mathrm{~nm}$ for Aegle marmelos, Punica granatum and Datura innoxia, respectively due to surface plasmon resonance (SPR) typical characteristic of AgNPs having kmax values which was reported earlier also in the visible range of wavelength $450-460 \mathrm{~nm}$ by Kreibig et al., (36). The sample was analyzed 
after centrifuging and redispensing in deionized water. The SPR band indicates the presence of spherical silver nanoparticles in the solution. It is reported that the SPR bands are influenced from shape, morphology, various size, composition as well as also dielectric constant of the synthesized nanoparticles. These results corroborate the findings of Rastogi and Arunachalam (37) for SNPs synthesis using aqueous garlic extract $(\mathrm{kmax}=414)$ under sunlight irradiation. Suman et al., (38) reported similar results for the SNPs synthesis using the root extract of Morinda citrifolia $(\mathrm{kmax}=$ $413 \mathrm{~nm}$ ). Previous studies have also shown that AgNPs at around $400 \mathrm{~nm}$ gives rise to the absorption bands in UV-Vis spectrum (39).

\subsection{Antimicrobial activity}

The silver nanoparticle solution synthesized by green method has shown highly toxic effect against Gram positive and Gram negative bacteria as well as fungal pathogens. The use of colloidal silver as antibacterial agent has been reported from ancient Greece (40). Silver nanoparticles are found to be very effective against micro-organisms because of their extremely high surface area. Several scientists are of opinion that silver ions, released from the AgNPs surface are responsible for their antibacterial activity (41). In present study, the antimicrobial activity of synthesized plant extracts SNPs was tested against gram positive (Staphylococcus aureus) and gram negative (Enterobactor aerogens) bacterial and fungal species Curvularia lunata and Aspergillus fumigatus using agar well-diffusion method. All tests were repeated thrice for each treatment and all plant-mediated SNPs did show inhibition zone against all studied bacterial and fungal pathogens.

\subsubsection{Antibacterial activity}

In the present study, the efficacy of $\mathrm{Ag}$ nanoparticles (AgNPs) produced from Punica granatum, Aegle marmelos and Datura innoxia aqueous leaf extract was studied against both gram positive (Staphylococcus aureus) and gram negative (Enterobactor aerogens) bacteria. The average antibacterial activity of synthesized AgNPs against bacterial strains ranged from 19.00 $\mathrm{mm}$ to $10.67 \mathrm{~mm}$ (the zone of inhibition) (Table 2). The silver nanoparticle synthesized using Datura innoxia showed maximum antibacterial activity for Staphylococcus aureus with $12.67 \mathrm{~mm}$ zone of inhibition and minimum activity 10.33 $\mathrm{mm}$ was observed in Punica granatum synthesized AgNPs. The maximum activity against Enterobactor aerogens was resulted in Aegle marmelos synthesized AgNPs with 19.00 $\mathrm{mm}$ zone of inhibition while Datura innoxia AgNPs showed minimum inhibitory activity15.33 $\mathrm{mm}$.
The diameter of zone of inhibition measured from Punica granatum synthesized AgNPs was $10.33 \mathrm{~mm}$ and $\mathrm{AgNO}_{3}$ solution and plant extract showed $5.00 \mathrm{~mm}$ and $4.65 \mathrm{~mm}$ respectively for Staphylococcus aureus. Indeed, Enterobactor aerogens showed $16.33 \mathrm{~mm}, 9.33$ $\mathrm{mm}$ and $5.67 \mathrm{~mm}$ zone of inhibition respectively for AgNPs, $\mathrm{AgNO}_{3}$ solution and Plant extract. The AgNPs synthesized using Aegle marmelos exhibited $10.67 \mathrm{~mm}$ zone of inhibition while 7.33 $\mathrm{mm}$ and $4.33 \mathrm{~mm}$ were observed respectively for $\mathrm{AgNO}_{3}$ solution and Plant extract against Staphylococcus aureus. In fact, in the case of Enterobactor aerogens, it was observed $19.00 \mathrm{~mm}$, $7.67 \mathrm{~mm}$ and $4.67 \mathrm{~mm}$ respectively for phytosynthesized AgNPs, $\mathrm{AgNO}_{3}$ solution and plant extract. AgNPs synthesized from Datura innoxia showed $12.67 \mathrm{~mm}$ while $9.33 \mathrm{~mm}$ and $6.33 \mathrm{~mm}$ diameter of zone of inhibition was observed for $\mathrm{AgNO}_{3}$ solution and plant extract respectively against Staphylococcus aureus. And for Enterobactor aerogens $15.33 \mathrm{~mm}, 10.33 \mathrm{~mm}$ and $7.00 \mathrm{~mm}$ zone of inhibition was observed for AgNPs, $\mathrm{AgNO}_{3}$ solution and Plant extract respectively.

In the present study, it was observed that synthesized AgNPs exhibit higher antimicrobial activity in comparison to $\mathrm{AgNO}_{3}$ and plant extracts. Reddy et al., (41) in his work suggested the less antibacterial activity of aqueous $P$. longum fruit extract (PLFE) in comparison to the green synthesized silver nanoparticles (PLAgNPs). The enhanced antibacterial activity of SNPs is due to the silver cations released from AgNPs that act as reservoir for the $\mathrm{Ag}^{+}$bactericidal agent. The weak DNA replication process and proteins inactivation are the important mechanisms for the antibacterial properties of synthesized metallic nanoparticles (42). $\mathrm{Ag}^{+}$strongly interacts with thiol group of fundamental enzymes and inactivates the enzyme activity (43). Experimental evidence indicates that DNA replication ability affects once the bacteria have been treated with silver ions (43-44). The accurate mechanism of the antibacterial effect of $\mathrm{Ag}^{+}$is partially understood, however, literature survey reveals that the positive charge on the Ag ion is vital for its antimicrobial activity $(44,45)$.

The antibacterial effect is probably resulting through the electrostatic attraction between negative charged cell membrane of microorganism and positive charged nanoparticles. Pal et al. (43) studied antibacterial activity against $E$. coli, $S$. aureus and Salmonella typhi and observed that the effect was dose dependent and was more evident against gramnegative compared to gram-positive bacteria. Kumar et al., (46) reported an in situ green biogenic synthesis of gold nanoparticles (AuNPs) using Terminalia chebula aqueous extracts as reducing and stabilizing agent and showed efficient activity towards gram positive Staphylococcus aureus compared to gram 
negative E. coli using standard well diffusion method.

\subsection{Antifungal activity}

In the present work, inhibition activity were evaluated against fungal pathogens and statistically analyzed. Phytosynthesized AgNPs showed higher antifungal activity in terms of inhibition zone followed by $\mathrm{AgNO}_{3}$ and with only plant extracts represented in Table 3. The antifungal activity of silver nanoparticles (AgNPs) produced from Punica granatum, Aegle marmelos and Datura innoxia aqueous leaf extract was studied against Curvularia lunata and Aspergillus fumigatus. The average antifungal activity of synthesized AgNPs against fungal pathogens ranged from $19.67 \mathrm{~mm}$ to $10.67 \mathrm{~mm}$ (the zone of inhibition) (Table 3).

Among the tested SNPs against selected fungal pathogens, AgNPs synthesized from Datura innoxia found to have higher antifungal activity against Aspergillus fumigatus with $19.67 \mathrm{~mm}$ where as Punica granatum AgNPs showed minimum activity with $15.33 \mathrm{~mm}$ (Zone of inhibition). In case of Curvularia lunata, it was observed that Datura innoxia synthesized AgNPs showed maximum 16.67 $\mathrm{mm}$ and Punica granatum exhibits minimum 10.67 $\mathrm{mm}$ zone of inhibition. The diameter zone of inhibition measured for phytosynthesized Punica granatum, Aegle marmelos and Datura innoxia AgNPs were $10.67 \mathrm{~mm}, 15.67 \mathrm{~mm}$ and $16.67 \mathrm{~mm}$ respectively against Curvularia lunata. AgNPs synthesized using Punica granatum, Aegle marmelos and Datura innoxia showed $15.33 \mathrm{~mm}, 19.00 \mathrm{~mm}$ and $19.67 \mathrm{~mm}$ zone of inhibition against $A$. fumigatus. The zone of inhibition observed for $\mathrm{AgNO}_{3}$ and Punica granatum plant extract was 9.33 $\mathrm{mm}$ and $6.67 \mathrm{~mm}$ against Curvularia lunata while $7.67 \mathrm{~mm}$ and $5.00 \mathrm{~mm}$ showed for Aspergillus fumigatus. Curvularia lunata showed $6.33 \mathrm{~mm}$ and $4.33 \mathrm{~mm}$ zone of inhibition for $\mathrm{AgNO}_{3}$ and Aegle marmelos extract respectively. The zone of inhibition was $9.33 \mathrm{~mm}$ and $6.00 \mathrm{~mm}$ for $\mathrm{AgNO}_{3}$ and Aegle marmelos extract against Aspergillus fumigatus. Diameter zone of inhibition exhibited for $\mathrm{AgNO}_{3}$ was $8.67 \mathrm{~mm}$ and for Datura innoxia extract $4.67 \mathrm{~mm}$ against Curvularia lunata. For Aspergillus fumigatus, the zone of inhibition was $7.33 \mathrm{~mm}$ and $5.67 \mathrm{~mm}$ respectively in the case of $\mathrm{AgNO}_{3}$ and Datura innoxia extract.

AgNPs synthesized using Datura innoxia showed maximum antifungal activity with $19.67 \mathrm{~mm}$ while Punica granatum synthesized SNP exhibited $15.33 \mathrm{~mm}$ against fungal pathogens Aspergillus fumigatus. For Curvularia lunata, Datura innoxia aqueous extract synthesized AgNP give maximum inhibitory activity of $16.67 \mathrm{~mm}$ and minimum 10.67 $\mathrm{mm}$ zone of inhibition was observed for Punica granatum extract synthesized AgNPs. Researchers have reported antifungal activities of silver nanoparticles (47). There are reports of several fungal strains showing effective drug resistance like
Fusarium solani, Candida albicans, Aspergillus flavus and Candida glaberata (48).

\section{Conclusion}

Plants or their extracts can be resourcefully used in the synthesis of silver nanoparticles with vast applications. Control over the shape and size of nanoparticles seems to be very simple with the use of plants. The nanoparticle synthesis using plant extract provides with acceptable morphology as well as size of nanoparticles. This approach for the synthesis of silver nanoparticles has many advantages such as, ease with which the process can be scaled up in affordable way, economic viability, and eco-friendly. The present study supports the medicinal values of these plants and also demonstrated a simple, rapid and economical route for the synthesis of silver nanoparticles; and their potential of rendering antimicrobial efficacy. Moreover the synthesized SNPs are highly stable and also reproducible, thus results in the improvement of the therapeutic effectiveness as well as emphasizes the medicinal values of these plants.

\section{Author Contribution Statement}

RD conducted the experiment and carried out the statistical analysis, KS designed and structured the experiment, and BG structured and wrote the manuscript.

\section{Conflict of Interest}

The author declares that she has no conflict of interest.

\section{Acknowledgments}

Authors are thankful to the Head, Department of Biotechnology, Guru Ghasidas Central University, Bilaspur for providing central laboratory facilities.

\section{References}

1. Klaus T, Joerger R, Olsson E, Granqvist C G. Silver based crystalline nanoparticles, microbially fabricated. Proceedings of the National Academy of Sciences of the United States of America. 1999; 96: 13611-14. https://doi.org/10.1073/pnas.96.24.13611

2. Konishi Y, Ohno K, Saitoh N. Bioreductive deposition of platinum nanoparticles on the bacterium Shewanella algae. Journal of Biotechnology. 2007;128:648-53. https://doi.org/10.1016/j.jbiotec.2006.11.014

3. Willner I, Baron R, Willner B. Growing metal nanoparticles by enzymes. Advanced Materials. 2006; 18:1109-20. https://doi.org/10.1002/adma.200501865

4. Shankar SS, Rai A, Ankamwar B, Singh A, Ahmad A, Sastry M. Biological synthesis of triangular gold nanoprisms. Nature Materials. 2004; 3: 482-8. https://doi.org/10.1038/nmat1152

5. Veerasamy R, Xin TZ, Gunasagaran S. Biosynthesis of silver nanoparticles using mangosteen leaf 
extract and evaluation of their antimicrobial activities. Journal of Saudi Chemical Society. 2011;15:

https://doi.org/10.1016/j.jscs.2010.06.004

113-20.

6. Dubey SP, Lahtinen M, Sillanpaa M. Tansy fruit mediated greener synthesis of silver and gold nanoparticles. Process Biochemistry. 2010; 45: 1065-71.

https://doi.org/10.1016/j.procbio.2010.03.024

7. Smitha SL, Philip D, Gopchandran KG. Green synthesis of gold nanoparticles using Cinnamomum zeylanicum leaf broth. Spectrochimica Acta Part A. 2009; 74: 735-9. https://doi.org/10.1016/j.saa.2009.08.007

8. Knoll B, Keilmann F. Near-field probing of vibrational absorption for chemical microscopy. Nature. $\quad 1999 ; \quad 399$ 134-7. https://doi.org/10.1038/20154

9. Sengupta S, Eavarone D, Capila I, Zhao G L, Watson $\mathrm{N}$, Kiziltepe T. Temporal targeting of tumour cells and neovasculature with a nanoscale delivery system. Nature. 2005; 436: 568-72. https://doi.org/10.1038/nature03794

10. Wiley BJ, Sun Y, Xia Y. Synthesis of silver nanostructures with controlled shapes and properties, Acc Chem Res. 2007; 40: 1067-76. https://doi.org/10.1021/ar7000974

11. Kumar V, Yadav SK. Plant-mediated synthesis of silver and gold nanoparticles and their applications. J Chem Technol Biotechnol. 2009; 84: 151-7. https://doi.org/10.1002/jctb.2023

12. Lee HJ, Yeo SY, Jeong SH. Antibacterial effect of nanosized silver colloidal solution on textile fabrics. J. Mater. Sci. 2003; 38: 2199-2204. https://doi.org/10.1023/A:1023736416361

13. Raffi M, Hussain F, Bhatti TM, Akhter JI, Hameed A, Hasan, MM. Antibacterial characterization of silver nanoparticles against E. coli ATCC-15224, J. Mater. Sci. Technol. 2008; 24: 192-196.

14. Ahmad MB, Shameli K, Darroudi M, Yunus WMZW, Ibrahim NA, Hamid AA, Zargar M. Antibacterial activity of silver/clay/chitosan bionanocomposites. Res. J. Biol Sci. 2009; 4:1156-61.

15. Jiang $\mathrm{H}$, Manolache $\mathrm{S}$, Wong ACL, Denes FS. Plasma-enhanced deposition of silver nanoparticles on to polymer and metal surfaces for the generation of antimicrobial characteristics. Journal of Applied Polymer Science. 2004; 93:141122. https://doi.org/10.1002/app.20561

16. Parikh DV, Fink T, Rajasekharan K. Antimicrobial silver/sodium carboxymethyl cotton dressings for burn wounds. Textile Research Journal. 2005; 75:1348. https://doi.org/10.1177/004051750507500208

17. Gosheger G, Hardes J, Ahrens H. Silver-coated megaendoprostheses in a rabbit model-an analysis of the infection rate and toxicological side effects. Biomaterials. 2004; 25:5547-56. https://doi.org/10.1016/j.biomaterials.2004.01.008

18. Rupp ME, Fitzgerald T, Marion N. Effect of silvercoated urinary catheters: efficacy, cost effectiveness, and antimicrobial resistance. American Journal of Infection Control. 2004, 32: 445-450. https://doi.org/10.1016/j.ajic.2004.05.002

19. Ohashi S, Saku S, Yamamoto K. Antibacterial activity of silver inorganic agent YDA filler. Journal of Oral Rehabilitation. 2004; 31: 364-7. https://doi.org/10.1111/j.1365-2842.2004.01200.x
20. Bosetti M, Masse A, Tobin E, Cannas M. Silver coated materials for external fixation devices: in vitro biocompatibility and genotoxicity.

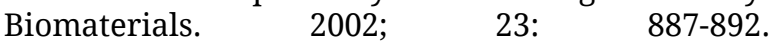
https://doi.org/10.1016/S0142-9612(01)00198-3

21. Lee HJ, Yeo SY, Jeong SH. Antibacterial effect of nanosized silver colloidal solution on textile fabrics. J. Mater. Sci. 2003; 38: 2199-2204. https://doi.org/10.1023/A:1023736416361

22. Sun Y, Xia Y. Shape-Controlled Synthesis of Gold and Silver Nanoparticles. Science. 2002; 298: 21769. https://doi.org/10.1126/science.1077229

23. Zargar M, Hamid AA, Bakar FA, Shamsudin MN, Shameli K, Jahanshiri F, Farahani F. Green synthesis and antibacterial effect of silver nanoparticles using Vitex negundo L. Molecules. 2011; 16: 6667-76 https://doi.org/10.3390/molecules16086667

24. Verma A, Mehata MS. Controllable synthesis of silver nanoparticles using Neem leaves and their antimicrobial activity. Journal of Radiation Research and Applied Sciences 2016; 9: 109-115. https://doi.org/10.1016/j.jrras.2015.11.001

25. Yan-yu R, Huia Y, Tao W, Chuang W. Green synthesis and antimicrobial activity of monodisperse silver nanoparticles synthesized using Ginkgo Bilobaleaf extractPhysics Letters A 2016; 380: 3773-3777.

26. Perez C, Pauli M, Bazerque P. An antibiotic assay by agar-well diffusion method. Acta Biologiae et Medicinal Experimentalis. 1990; 15:113-5.

27. Talibi I, Askarne L, Boubaker H, Boudyach EH, Msanda F, Saadi B. Antifungal activity of some Moroccan plants against Geotrichum candidum, causal agent of postharvest citrus sour rot. Crop Prot. 2012; 35:41-6. https://doi.org/10.1016/j.cropro.2011.12.016

28. Ahmad N, Sharma S, Alam MK, Singh VN, Shamsi SF, Mehta BR, Fatma A. Rapid synthesis of silver nanoparticles using dried medicinal plant of basil. Colloids Surf B. 2010; 81: 81-6. https://doi.org/10.1016/j.colsurfb.2010.06.029

29. Parsons JG, Peralta-Videa JR, Gardea-Torresdey JL. Use of plants in biotechnology: Synthesis of metal nanoparticles by inactivated plant tissues, plant extract, and living plants. In: Sarkar D, Datta R, Hannigan $\mathrm{R}$ editors. Developments in Environmental Science 2005; 5: p. 463-85.

30. Kumar V, Yadav SC, Yadav SK. Syzygium cumini leaf and seed extract mediated biosynthesis of silver nanoparticles and their characterization. J Chem Technol Biotechnol. 2010; 85:1301-9. https://doi.org/10.1002/jctb.2427

31. Jain D, Kumar D, Kachhwaha S, Kothari S. Synthesis of plant mediated silver nanoparticles using Papaya Fruit Extract and Evaluation of their Antimicrobial Activities. Digest. Journal of Nanomaterials and Biostructures. 2009; 4:557-63.

32. Rai A, Singh A, Sastry M. Role of halide ions and temperature on the morphology of biologically synthesized gold nanotriangles. Langmuir. 2006; 22:736-41. https://doi.org/10.1021/la052055q

33. Noginov MA, Zhu G, Bahuoura M, Adegoke J, Ritzo BA. The effect of gain and absorption on surface Plasmon in metal nanoparticles. Appl. Phys. B. 2006; 86:455-60. https://doi.org/10.1007/s00340-0062401-0 
34. Roopan S, Rohit M, Rahuman A,. Kamaraj C, Bharathi A. Low-cost and ecofriendly phyto-synthesis of silver nanoparticles using Cocos nucifera coir extract and its larvicidal activity. Industrial Crops and Products. 2013; 43:631-5. https://doi.org/10.1016/j.indcrop.2012.08.013

35. Kelly KL, Coronado E, Zhao LL, Schatz GC. The optical properties of metal nanoparticles: The influence of size, shape and dielectric environment. J. Phys. Chem. B. 2003; 107:668-77. https://doi.org/10.1021/jp026731y

36. Kreibig U, Vollmer M. Optical Properties of Metal Clusters; Springer: Berlin, Germany. 1995; p.14-41. https://doi.org/10.1007/978-3-662-09109-8

37. Rastogi L, Arunachalam J. Sunlight based irradiation strategy for rapid green synthesis of highly stable silver nanoparticles using aqueous garlic (Allium sativum) extract and their antibacterial potential. Mater. Chem. Phys. 2011; 129:558-63. https://doi.org/10.1016/j.matchemphys.2011.04.068

38. Suman TY, Rajasree SRR, Kanchana A, Elizabeth SB. Biosynthesis, characterization and cytotoxic effect of plant mediated silver nanoparticles using Morinda citrifolia root extract. Colloids Surf. B Biointerfaces. 2013; https://doi.org/10.1016/j.colsurfb.2013.01.037

106:74-8.

39. Chandran SP, Chaudhary M, Pasricha R, Ahmad A, Sastry M. Synthesis of gold nanotriangles and silver nanoparticles using Aloe vera plant Extract. Biotechnology progress. 2006; 22: 577-83. https://doi.org/10.1021/bp0501423

40. Morones JR, Elechiguerra JL, Camacho A. The bactericidal effect of silver nanoparticles. Nanotechnology. 2005; 16: 2346-53. https://doi.org/10.1088/0957-4484/16/10/059

41. Reddy NJ, Vali DN, Rani M, Rani SS. Evaluation of antioxidant, antibacterial and cytotoxic effects of green synthesized silver nanoparticles by Piper longum fruit. Mater. Sci. Eng. C. 2014; 34:115-22. https://doi.org/10.1016/j.msec.2013.08.039
42. Lee HY, Park HK, Lee YM, Kim K, Park SB. Silver nanoparticles and its antibacterial evaluation for biomedical applications. Chem. Comm. 2007; 28: 2885 .

43. Pal S, Tak YK, Song JM. Does the antibacterial activity of silver nanoparticles depend on the shape of the Nanoparticle? A study of the gramnegative bacterium Escherichia coli. Appl. Environ. Microbiol. 2007; 73:1712-20. https://doi.org/10.1128/AEM.02218-06

44. Vivek M, Kumar PS, Steffi S, Sudha S. Biogenic silver nanoparticles by Gelidiella acerosa extract and their antifungal effects. Avicenna J. Med. Biotechnol. 2011; 3:143.

45. Dibrov P, Dzioba J, Gosink KK, Hase CC. Chemiosmotic mechanism of antimicrobial activity of $\mathrm{Ag}(+)$ in Vibrio cholerae. Antimicrob. Agents Chemother. 2002; 46: 2668-70. https://doi.org/10.1128/AAC.46.8.2668-2670.2002

46. Kumar KM, Mandal BK, Sinha M, Krishnakumar V. Terminalia chebula mediated green and rapid synthesis of gold nanoparticles. Spectrochim. Acta A: Mol. Biomol. Spectrosc. 2012; 86:490494. https://doi.org/10.1016/j.saa.2011.11.001

47. Udayakumar R, Velmurugan K, Srinivasan D, Krishna RR. Phytochemical and antimicrobial studies of extracts of Solanum Xanthocarpum. Ancient Science of Life. 2003; 23:1-7.

48. Saha S, Dhanasekaran D, Chandraleka S, Panneerselvam A. Synthesis, characterization and antimicrobial activity of cobalt metal complex against multi drug resistant bacterial and fungal pathogens. Facta Universitatis Series Phys. Chem. Technol. 2009; 7:73-80. https://doi.org/10.2298/FUPCT0901073S 